\title{
Towards a Vocabulary to Implement Culturally Relevant Relationships Between Digital Collections in Heritage Institutions ${ }^{\dagger}$
}

\author{
Carlos H. Marcondes
}

Post-graduate Program on Information Science, Federal Fluminense University, R. Lara Vilela 126, São Domingos, CEP 24210-590, Niterói, Rio de Janeiro, Brazil, <ch_marcondes@id.uff.br>

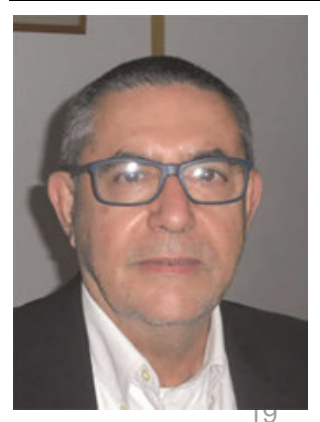

Carlos H. Marcondes is Full Professor at Federal Fluminense University, where he is coordinator of the Knowledge Organization in Digital Environments Research Group. He is also Visiting Professor at Minas Gerais Federal University, Associated Researcher of the National Council for Scientific Development and of Complutense Univesity, Madrid, Spain, and consultant of several public and private projects of KOSs.

Marcondes, Carlos H. 2020. “Towards a Vocabulary to ImplementCulturally Relevant Relationships between Digital Collectionsin Heritage Institutions.” Knowledge Organization 47(2): 122-137. 44 references. DOI:10.5771/0943-74442020-2-122.

Abstract: Cultural heritage institutions are publishing their digital collections over the web as LOD. This is is a new step in the patrimonialization and curatorial processes developed by such institutions. Many of these collections are thematically superimposed and complementary. Frequently, objects in these collections present culturally relevant relationships, such as a book about a painting, or a draft or sketch of a famous painting, etc. LOD technology enables such heritage records to be interlinked, achieving interoperability and adding value to digital collections, thus empowering heritage institutions. An aim of this research is characterizing such culturally relevant relationships and organizing them in a vocabulary. Use cases or examples of relationships between objects suggested by curators or mentioned in literature and in the conceptual models as FRBR/LRM, CIDOC CRM and RiC-CM, were collected and used as examples or inspiration of cultural relevant relationships. Relationships identified are collated and compared for identifying those with the same or similar meaning, synthesized and normalized. A set of thirty-three culturally relevant relationships are identified and formalized as a LOD property vocabulary to be used by digital curators to interlink digital collections. The results presented are provisional and a starting point to be discussed, tested, and enhanced.

Received: 10 September 2019; Revised: 3 January 2020, 24 January 2020, 26 January 2020; Accepted: 27 January 2020

Keywords: relationships, cultural heritage, digital collections, digital heritage object (HO)

† The author is grateful for the many use cases suggested by heritage institutions curators and for the contributions from Europeana Tech and OpenGLAM mailing lists; this work was carried out with the support of the Brazilian agencies CAPES-Financing Code 001 and CNPq, grant number 305253/2017-4. I also am grateful for the valuable contributions of the reviewers.

The Semantic web isn't just about putting data on the web. It is about making links so that a person or machine can explore the web of data. With linked data, when you have some of it, you can find other, related, data.

Berners-Lee 2006

\subsection{Introduction}

From a cultural standpoint, what are the relationships between the first edition of the Don Quijote de La Mancha by Cervantes Saavedra, which is in the collection of the Biblioteca Nacional de España and the etching by Pablo Picasso portraying Don Quijote and Sancho Panza, which is in the collection of MOMA - the Museum of Modern Art-in New York City? What might be the relationships between heritage objects of different collections that are being published according to linked open data (LOD) technologies? Such resources and many others belonging to the collections of different heritage institutions are now being published according to LOD technologies. They may be integrated into a unique and significant virtual resource that makes sense and contributes to cultural understanding. The facilities offered by LOD technologies enables digital objects of different collections to be mobilized by curators in specific domains such as art, culture, literature, history, journalism, education, scientific scholarly communication, travel and cultural tourism, etc., in order to create a new, unique, curated, digital resource, such as virtual exhibitions and educational resources. 
C. H. Marcondes. Towards a Vocabulary to ImplementCulturally Relevant Relationships ...

Cultural heritage objects hold different types of relationships. A film may be inspired by a literary work, an etching becomes an illustration in an edition of a literary work, famous painters created the scenario and costumes of ballets or assembly plays. There are different versions of Da Vinci's Mona Lisa created by artists such as Marcel Duchamp, Andy Warhol, and Fernando Botero. In knowledge organization literature, such relationships are similar to associative relationships.

However, due to a long-time tradition of independent, self-contained collections and the adoption of different standards, the possibilities of interoperability between such diverse collections are beyond technological issues. In recent years, documentation as a domain has used conceptual models to identify, make explicit, standardize, and semantically integrate their objects. LOD technologies enable such semantic relationships to no longer remain within the scope of a specific collection's domain but rather within a wider scope of subject domains comprising heritage objects-and their digital representations-belonging to different collections.

A digital curator, with the aim of a formalized vocabulary of such relationships, could produce culturally rich virtual collections of archives, libraries, museums, and educational resources, accessible by anybody from anywhere, by exploring the increasing number of memory and cultural heritage collections now available throughout the web. These technologies enable a digital curator to discover and make sense of, or propose new, unforeseen, semantic relationships between digital cultural heritage objects belonging to different collections. Besides that, the implementation of semantic links using LOD technologies can achieve interoperability between digital collections.

What culturally relevant relationships may exist between digital objects of collections or fonds in archives, libraries, and museums? How can such relationships be discovered, identified, and classified? How can LOD technologies be used to implement such relationships as semantic links? How could such relationships be useful for art, history, or culture curators to annotate and enrich digital heritage objects?

This research aims to discuss and characterize such culturally relevant relationships, compiling an inventory and organizing them in a vocabulary. In this paper I expand upon and deepen the conclusions of previous work (Marcondes and Campos 2016; Marcondes 2018a; Marcondes 2018c). With this research I also aim to improve the usability of digital collections in archives, libraries, and museums, thus empowering heritage institutions. The paper is organized as follows: after the introduction, Section 2 describes the potential of publishing heritage collections as LOD; Section 3 reviews theoretical issues concerning relationships in knowledge organization, with a focus on associative rela- tionships; Section 4 presents the materials and methods used, the assumptions related to precisely characterizing the objects being related and their digital representations, and develops a framework for the analysis of the relationships compiled; Section 5 presents the results-the thirty-three relationships found; and, Section 6 provides final remarks and conclusions.

\subsection{Potential of LOD in heritage institutions}

Since the publication of the Library Linked Data Incubator Group Final Report in 2011 (W3C Incubator Group Report 2011), LOD technologies applied to heritage digital collections in archives, libraries, and museums seem to have reached the first stage of maturity (Agenjo-Bullón 2015). These institutions, the GLAM-galleries, libraries, archives and museums-sector, have also been empowered by initiatives such as OpenGLAM (https://openglam.org/), which states as its mission "an initiative run by Open Knowledge that promotes free and open access to digital cultural heritage held by Galleries, Libraries, Archives and Museums." Reuse is a major issue when publishing digital heritage collections. When such collections are free and open access, they constitute input and raw material for creative industries, education, publishing, tourism, and other economic sectors. Indeed, there now are many successful experiences of publishing not only important collections encompassing archives, libraries, and museums, but also several LOD vocabularies (Zeng 2018).

Archives, libraries, and museums around the world are developing projects to publish their catalogs using LOD. Among the most significant are those of the Biblioteca Nacional de España (http://datos.bne.es), the British Library (http://bnb.data.bl.uk/), the Deutsche National Bibliothek (http://www.dnb.de/EN/Service/DigitaleDienste/ LinkedData/linkeddata_node.html), the Bibliothèque $\mathrm{Na}$ tionale de France (http://data.bnf.fr), the Europeana Library (https://pro.europeana.eu/page/linked-open-data), the British Museum (https://old.datahub.io/dataset/british-museum-collection), the Archives Hub (https://archiveshub.jisc.ac.uk/), and The American Art Collaborative Linked Open Data Consortium (https://american art.si.edu/about/lod/aac.).

Among vocabularies published as LOD are the Library of Congress Subject Headings-LC Linked Data Service (http://id.loc.gov/authorities/subjects.html) and the Getty Vocabularies as Linked Open Data (http://www. getty.edu/research/tools/vocabularies/). LOD vocabularies are essential to assign semantics to published data. Besides that, in recent years Wikipedia, Wikidata, and DBpedia (Estermann 2018) have been playing a central role as data hubs, connecting cultural heritage collections published as linked data over the web. 
According to Tim Berners-Lee (2006), LOD is not only about publishing data. Such technologies will achieve their full potential as the published resources became "interlinked." To take full advantage of LOD is not sufficient to publish heritage data according to LOD technologies. For many years, cultural heritage institutions have developed curatorial processes over the collections they oversee as continuous value-adding processes. These institutions are now beginning to publish their collections as digital objects over the web. Despite the advances of web catalogue archives, library and museum collections are still dependent on catalogue systems and technologies, which do not fully allow integration of their data with other resources available throughout the web.

Accordingly, LOD technologies allow the curatorial work done by memory and culture institutions to advance to a new level. The emergence of semantic web and LOD technologies enable cross-searching and the interlinking of digital objects belonging to different collections over the web, achieving interoperability between different collections (Zeng 2019). The LOD environment thus creates unexpected meaning and rich contextual networks, empowering the synergies of collections, their complementarities, and their educational and curatorial potentials.

LOD technologies are based on a simple descriptive data model comprising RDF (2014)—resource description framework-triples: the resource being described, the properties of such resources, and the values of such properties. Examples of archive, library, and museum objects described according to the LOD triple model can be seen in Wikidata (https://www.mediawiki.org/wiki/Wikibase/ DataModel/Primer) items for the Magna Carta and The Don Quijote by Cervantes Saavedra and the Mona Lisa by Da Vinci. It comprises a simple, unified model through which archives, libraries, and museum objects can all be described. Such technologies enable direct publication of digital collections and their integration into the mainstream web. Many of these collections are thematically superimposed and complementary, having synergies not yet explored. Such technological facilities enable complementarity to be activated for the benefit of heritage institutions, culture, and education. According to Constantopoulos and Dallas $(2007,8)$

A study of current digital curation research and advocacy suggests that the scope of digital curation work needs to expand significantly, particularly as regards the goal of ensuring epistemic adequacy of information in yet unknown future contexts of use, and advances the view that validity and usefulness of digital information objects for "fitness for purpose" depends, crucially, on adequate knowledge representation.
55 The same authors claim (Constantopoulos and Dallas 56 2008, 5) that curatorial work includes "ensuring the ability 57 to discover and access inter- and intra-domain associations 58 and to overlay context dependent interpretations." Fre59 quently these collections present culturally relevant rela60 tionships between their objects, like a book about a 61 painting, drawings illustrating a literary work, a draft or 62 sketch of a famous painting, a letter from an author com63 menting on a book or painting, or a contract to commis64 sion a sculpture or artwork, etc. With the publication of 65 digital collections of GLAMs, the interlinking of such col66 lections, a new curatorial activity, will produce richer and 67 more comprehensive web resources.

68 Curatorial work is multidisciplinary, hard to delimit, per69 sonal, and authorial. Consider, for example, traveling exhi70 bitions that have been exhibited in many countries such as 71 Leonardo Da Vinci: The Mechanics of a Genius or Human Bod72 ies: The Exbibition. Consider also how the exploitation of 73 the curatorial potential of LOD technologies could en74 hance such exhibitions. They could be virtual exhibitions 75 with a much broader reach, reaching far more people.
76

\subsection{Relationships in knowledge organization}

Research in information science and knowledge organization, especially in domains such as indexing languages, coordinated indexing systems, and information retrieval, gives special attention to relationships as keys for representing meaning (Khoo and $\mathrm{Na}$ 2006; Green 2001). The Relational Indexing proposal states (Farradane 1980, 267) that "a method of structuring terms from the vocabulary to express the meaning between words." Conventional thesaurus relationships are generally classified in paradigmatic and syntagmatic relationships. The paradigmatic relationships are the hierarchical relations that form the taxonomic structure paradigm of things in a domain. Associative relations are sometimes defined by exclusion of hierarchical or paradigmatic relationships. Marcia Lei Zeng (2005) defines them as: "This relationship covers associations between terms that are neither equivalent nor hierarchical, yet the terms are semantically or conceptually associated." Associative relationships are thus dubious and semantically inaccurate. They are also highly context dependent.

Tillet (2001) provides a taxonomy of the bibliographic relationships, mostly consolidated in the IFLA FRBR (1978) and LRM (Riva et al. 2017) bibliographic conceptual models. Conceptual models as the IFLA FRBR (1997) and LRM (Riva et al. 2017), the CIDOC Conceptual Reference Model (2014) and the RiC-CM (International Council on Archives 2016) provide richer sets of relationships.

The relationships we are looking for are relationships between heritage objects in collections belonging to heritage institutions as archives, libraries, and museums. FRBR and 
C. H. Marcondes. Towards a Vocabulary to ImplementCulturally Relevant Relationships ...

1 its updated version, the $L R M$, have as their core the notion 2 of work as "The intellectual or artistic content of a distinct creation" (Riva et al. 2017, 21). Rigorously speaking in terms of IFLA $L R M / F R B R$, they are relationships between items. But in the case of culturally relevant relationships they inherit the work to work, work to manifestation, work to item relationships as described and exemplified in IFLA (1997, 56) Chapter 5 and LRM (Riva et al. 2017, 64) Table 4.7. A fundamental distinction made in the FRBR model concerning the domain and range of a relationship is between "autonomous" and "referential" works, i.e., the grade a work is dependent-independent of another related work. We used this distinction in the analytical frameworks presented in Section 3.3 .

Modern bibliographic description standards largely take advantage of relationships. The Resource Description and Access Joint Steering Committee for Development of $\mathrm{RDA}$ 2015) - RDA - the bibliographic descriptive standard conceived to replace the Anglo-American Cataloguing Rules, 2nd Edition Revised (AACR2), gives special emphasis to relationships. Detailed descriptions of different types of relationships - those primary between work, expression, manifestation, and item, those to persons, families, and corporate bodies, those to concepts, objects, events, and places, those between those work, expression, manifestation, and item, those between those persons, families, and corporate bodies, and those between those concepts, objects, events, and places are provide in $R D A$ 's sections five to ten.

BIBFRAME-Bibliographic Framework Initiativethe bibliographic description and exchange coding schema, built on the foundation of $\mathrm{RD} A$ and the successor of the MARC bibliographic format, largely takes advantage of LOD technologies to implement relationships and provide a richer context to bibliographic entities: "BIBFRAME provides a foundation for the future of bibliographic description, both on the web, and in the broader networked world that is grounded in Linked Data techniques" (Library of Congress).

\subsection{Methodology}

\subsection{Material and method}

Bibliographic and document sources about the patrimonialization and curatorial processes developed by archives, libraries, and museums were sought to supply definitions of concepts such as archives, collections, items, records, and cultural heritage objects. Conceptual models such as IFLA's (1997) FRBR, the LRM (Riva et al. 2017), the CIDOC CRM (CIDOC Conceptual Reference Model 2014), the EDM (Europeana 2017), the RiC-CM (International Council on Archives 2016) and vocabularies such as ATT (Art \& Architecture Thesaurus) were examined as sources to identify possible relationships between objects. Use cases or examples of relationships between objects suggested by curators of archives, libraries, and museums or mentioned in literature, were also collected and used as examples of possible relationships; examples of forms used to collect use cases can be found in Appendix 1. Use cases and examples of relationships were also suggested by members of Europeana Tech and OpenGLAM mailing lists. Sites of exhibitions as Leonardo Da Vinci: The Mechanics of a Genius or Human Bodies: The Exhibition were also consulted.

The relationships thus identified were starting points to derive culturally relevant relationships. To each relationship a question was posed: How could this relationship be generalized to relate heritage objects belonging to different collections in archives, libraries, and museums? Among the relationships found in the different conceptual models, IFLA $(1997,56)$ Chapter 5 section 5.3 and LRM (Riva et al. 2017, 64) Table 4.7 proposes a set of important relationship cases to the development of culturally relevant relationships.

A framework to analyze and organize the collected relationships was also developed, based on the top-level relationship schema between entities of groups 1,2, and 3 of the FRBR model. The FRBR model was chosen, because it is primarily oriented to objects (it is concerned with relationships between objects in library collections, the group 3 entities), while the CIDOC CRM and EDM are mainly event oriented. A deductive process based on such a framework, combined with an inductive process based on the cases collected, were used to reach the results.

\subsection{Assumptions}

What are the objects in collections of archives, libraries, and museums that we intend to relate to each other? According to Van Mensch $(1992,104)$, “The museum object is considered to be the basic unit of the museum working procedures." Van Mensch claims that "Museum objects are objects separated from their original (primary) context and transferred to a new, museum reality in order to document the reality from which they were separated."

Access through the web to collections of heritage objects presupposes their representation in digital formats. The digital objects that are published and interlinked 8 throughout the web using LOD technologies are indeed 9 artifacts, even if the original object it is based is a natural object (Marcondes, 2019). In this sense, they are social cre01 ations (Searle 1995). They are knowledge tools-arti102 facts - created on the foundations of archive, library, and 103 museum methodologies and standards. They are complex 104 digital objects, here called digital HO_-digital heritage ob105 ject, and, within the context of LOD technologies, identi106 fied by a unique identifier, along with metadata about both 
the $\mathrm{HO}$ itself and its digital representations: digital images or copies of the physical object. Such metadata provide context and access points and enable the management of digital HOs in the digital environment. We consider the original physical heritage objects- $\mathrm{HO}$ - of a priori cultural relevance, as they are the result of curatorial processes developed by heritage institutions; their digital surrogates inherit their cultural relevance, forming a new collection or resource to be curated. A HO is a specific item in a heritage institution collection, in the senses of FRBR (1997) and IFLA LRM (Riva et al. 2017). Culturally relevant relationships interlink $\mathrm{HO}$ digital surrogates.

An important requirement is that culturally relevant relationships should be simple and intuitive as they are thought to be used by digital curators such as art, literature, and culture historians and critics, journalists, and educators in mind.

\subsection{A framework to analyze relationships between cultural heritage objects}

A framework is presented here along with its conceptual basis, developed to analyze the suggested and the compiled relationships. The framework consists of a table cross-relating heritage objects $(\mathrm{HO})$ according to the type of heritage institution, archives, libraries, or museum heritage objects; line titles represent the domains, column titles represent the range of the relationships of the suggested use cases, and cells represent a specific relationship, as the relationship "inspired," between the novel Iracema, typically a library object $(\mathrm{HO})$ and the painting "Iracema," a typical museum object (mHO, see Appendix 1). To these HO, "monuments" (monHO) was also added, as there are several suggested use cases that include relationships between archive, library, and museum objects with monuments. For analytical purposes, $\mathrm{HO}$ were subdivided into $\mathrm{aHO}$, for archives digital heritage object, $1 \mathrm{HO}$ for library digital heritage object, $\mathrm{mHO}$ for museum digital heritage object and monHO for museum digital heritage object. Such objects are related to other objects, namely agents (FRBR group two entities), concepts, events, time, and place (FRBR group three entities). See Table 1 below. 84 dia-types/media-types.xhtml). However, the classification

Each table cell contains a direct relationship from the entity represented by the specific line to the entity represented by the specific column. The entity in the cell line is the domain, and the entity in the column is the range of the relationship. For example, cell twenty-three represents a book in a library and an etching that illustrates it in a museum ( $1 \mathrm{HO} \mathrm{X} \mathrm{mHO})$. As we ask for heritage institution curators to suggest cases of relationships between objects in collections of different heritage institutions, the framework we have developed reflects relationships where domain and range are objects in archives, libraries, and museum collections. HO, i.e., archive, library, and museum objects, may be further specialized into different types of objects as is usual in archive, library, and museum collections management. All relationships are also similar to associative relationships largely used in thesaurus theory and construction.

Within the scope of LOD technologies, a common feature is the use of multiple and specialized vocabularies (Zeng 2018). In LOD vocabularies, the domain and range of the relationships cannot be specified by the type of heritage institution as was done in the table just presented. For example, in the "documents" relationship (relationship ID: 0041), for the suggested case of Darwin's Beagle's expedition field notebook, the domain is an archive $\mathrm{HO}$ and the range, the species collected by him, is a museum HO. However, in many cases, a field notebook may belong to the collection of a library or museum. The previously mentioned table is just a tool for systematizing the case relationships collected. A requisite of vocabularies expressed as semantic web technologies that comprise classes of objects and the relationships among them is that the relationship specifications must include the domain and range.

Accordingly, a new classification of types of $\mathrm{HO}$ must be proposed that has as a basis in the "expression forms" of $\mathrm{HO}$; domain and range are specified according to specific types of "expression forms" of HO, i.e, "how each object is expressed or manifested" to human senses. Such a classification is developed, inspires, and is used for similar purposes as edm:types and the IANA list of internet media types (https://www.iana.org/assignments/me

\begin{tabular}{|l|c|c|c|c|c|c|c|c|c|}
\hline & aHO & 1HO & mHO & monHO & Agent & Concept & Events/Processes & Time & Place \\
\hline aHO & 11 & 12 & 13 & 14 & 15 & 16 & 17 & 18 & 19 \\
\hline lHO & 21 & 22 & 23 & 24 & 25 & 26 & 27 & 28 & 29 \\
\hline mHO & 31 & 32 & 33 & 34 & 35 & 36 & 37 & 38 & 39 \\
\hline monHO & 41 & 42 & 43 & 44 & 45 & 46 & 47 & 48 & 49 \\
\hline Agent & 51 & 52 & 53 & 54 & & & & & \\
\hline Concept & 61 & 62 & 63 & 64 & & & & & \\
\hline Events/ Processes & 71 & 72 & 73 & 74 & & & & & \\
\hline Time & 81 & 82 & 83 & 84 & & & & & \\
\hline Place & 91 & 92 & 93 & 94 & & & & & \\
\hline
\end{tabular}

Table 1. Relationships between heritage objects. 
of types of expression forms is applied not to the HOs' 2 digital representations as the aforementioned ones but to 3 the "original" HO. An expression form specifies the form in which an original HO is perceived by humans' senses: taste, sight, touch, smell, and hearing. The classification pro6 posed has seven types of expression forms an HO may have: "three_dimensional objects" (perceived mainly by sight and touch: physical objects such as a sword, a chair, a sculpture), "two_dimensional objects" (perceived mainly by sight: objects frequently classified as iconography such as a painting, a drawing, an engraving, an illustration, a poster, a photograph, maps), "text_objects" (perceived mainly by sight: books, letters, manuscripts), "moving_images objects" (perceived mainly by sight: films), "sound objects" (per5 ceived mainly by hearing: recorded music), "three_dimensional_image objects" (perceived mainly by sight: photogrammetry images).

Although "expression form" is a consistent criterion, by definition, any digital $\mathrm{HO}$ is rendered in a digital format. Further discussion is needed regarding the correspondence of the expression forms proposed to digital formats. This decision is due to the complexity of the adoption of any of the existing classification of types of HOs, each of them having their pros and cons. A notorious lack of consensus 5 and standards of types of heritage objects exists, and the adoption of such a classification would be polemic.

"Dependence" is a fundamental criterion to analyze and classify relationships. Are there several types of dependence? Following Guarino (1997), Guarino and Welty (2000b), and IFLA (1997) on "existential dependence" and "referential" and "autonomous" relationships, we question if any of the relata in the relationships found are existentially

\subsection{Results and discussion}

What are culturally relevant relationships? For the purposes of this work, they are relationships that contextualize and enhance the cultural comprehension of a heritage object. Here they are classified in direct relationships, such as between a book and a aquatint inspired on it (e.g., the previously mentioned work Don Quijote de La Mancha and the aquatint by Picasso portraying Don Quijote and Sancho Panza), and indirect ones, such the relationships between heritage objects and external entities such as between a book or a painting and its author (agent) or subject, or an painting depicting an event or process (the IFLA FRBR group one relationships to group two and three entities).

Such relationships may be directly or automatically derived from records in catalogs, according to established rules (Marcondes 2018b), such as between two books with common properties, i.e., the same title, as in the previous example of Don Quijote, or between a book and its author.

Yet, such relationships can also be authorial: different cultural experts and curators, such as art and literary critics, historians, educators, journalists, scholars, etc., discover, illuminate, evaluate, relate to, interpret, and show different points of view about historical facts or processes, historical characters, and artifacts, etc. While doing their job, these experts may find or propose authorial relationships between such entities not previously perceived by anyone else. The vocabulary was developed under the prerequisite that the relationships should be general and intuitive in order to be used by curators in annotating cultural heritage collections.

\subsection{Criteria for analyzing the relationships.}

From the theoretical basis used and from the use cases suggested and found in literature, emerged an initial set of criteria for the organization of the relationships. Such criteria are something like and inspired in what Guarino and Welty (2000a) call "meta-properties:"

- Cultural association (CA): when there is a relationship between two HOs or between a $\mathrm{HO}$ and another entity, established not by the creator of any of them, but by a "third-party agent," for example, by a curator, a literary or art critic. Cultural association means that the two HOs are existentially independent.

- Cultural dependence (CD): when two HOs have a relationship established by the creator of one of them; the creator of one HO intended for the other HO; the two HOs are both artifacts.

- Cultural independence (CI): when two HOs have a relationship established by the creator of one of them, the creator of one $\mathrm{HO}$ intended for the other $\mathrm{HO}$, but 
only one of the HOs is an artifact, whereas the other one is originally a natural object.

- Cultural dependence (CD): when two HOs have a relationship established by the creator of one of them; the creator of one $\mathrm{HO}$ intended for the other HO; the two HOs are both artifacts.

- Existential independence (EI): when the two HOs exist independently of each other.

- Intersection (IS): both HO share at least one common property, e.g., a common title or belong to the same culture or have the same artistic style, period, or are made of the same material or technique.

Another criterion that seems to define how two $\mathrm{HO}$ are related is the type of expression form. Accordingly, in many cases, the domain and range are specified according to HOs restricted to specific types of expression form.

\subsection{Relationships identified}

\begin{tabular}{|c|c|}
\hline \multicolumn{2}{|c|}{ Based_on relationship } \\
\hline \multicolumn{2}{|c|}{ Relationship ID: 0011} \\
\hline Label & $\begin{array}{l}\text { "Based_on”@en, "Baseado_em”@pt, } \\
\text { "Basado_en”@es }\end{array}$ \\
\hline URI & $\begin{array}{l}\text { http://culturally_relevant_relationships.org/ } \\
0011 /\end{array}$ \\
\hline Description & $\begin{array}{l}\text { This type of relationship presupposes an } \\
\text { original, previous work, and another } \\
\text { based_on work. It encompasses all kinds of } \\
\text { pragmatic replicas or artistic copies, re- } \\
\text { creations, revisits, and re-readings of a work; } \\
\text { it is concerned directly with works in the } \\
\text { FRBR model sense. A work is based on } \\
\text { another if the based-on work carries at least } \\
\text { one property of the base work: a book } \\
\text { (lHO) that is based_on another (lHO): cell } \\
\text { twenty-two; an artwork (mHO) that is the } \\
\text { base for another mHO): cell thirty-three; a } \\
\text { monument (monHO) that is the base for } \\
\text { another (monHO): cell forty-four. }\end{array}$ \\
\hline Domain & $\mathrm{HO}$ \\
\hline Range & $\mathrm{HO}$ \\
\hline Criteria & $\begin{array}{l}\mathrm{CD} \text {, the expression form of both the } \\
\text { based_on } \mathrm{HO} \text { and the base_for } H O \text { are the } \\
\text { same. }\end{array}$ \\
\hline Examples & $\begin{array}{l}\text { Many works show literary influence of } \\
\text { Hamlet (by Shakespeare), such as Hamlet for } \\
\text { Kids (Shakespeare Can Be Fun!) by Lois } \\
\text { Burdett; the design of Federal Hall in New } \\
\text { York City is based_on the design of the } \\
\text { Parthenon in Athens; the different based_on } \\
\text { versions of Da Vinci's Mona Lisa by artists } \\
\text { such as Dali, Botero, Andy Warhol, etc. }\end{array}$ \\
\hline $\begin{array}{l}\text { Similar } \\
\text { relationships }\end{array}$ & $\begin{array}{l}\text { The FRBR model has many types of work- } \\
\text { to-work relationships such as, frbr:is an } \\
\text { imitation of, frbr:is a transformation of, } \\
\text { frbr:is an adaptation of; Getty att:pastiche }\end{array}$ \\
\hline $\begin{array}{l}\text { Inverse } \\
\text { Relationship }\end{array}$ & Base_for, Relationship ID: 0012 \\
\hline
\end{tabular}

Table 2. Based_on X base_for relationships.

\begin{tabular}{|l|l|}
\hline \multicolumn{2}{|l|}{ Created_by relationship } \\
\hline Relationship ID:0021 \\
\hline Label & $\begin{array}{l}\text { "Created_by"@en, “Criado_por”@pt, } \\
\text { "Creado_por”@es }\end{array}$ \\
\hline URI & $\begin{array}{l}\text { http://culturally_relevant_relationships.org/ } \\
0021 /\end{array}$ \\
\hline Description & $\begin{array}{l}\text { The relationship between an intellectual, } \\
\text { artistic, or technical work embodied in a HO } \\
\text { and the agent responsible for its creation }\end{array}$ \\
\hline Domain & HO \\
\hline Range & Agent \\
\hline Criteria & $\begin{array}{l}\text { Mona Lisa was created_by Da Vinci; } \\
\text { Guernica } \text { was created_by Picasso; Ford } \\
\text { Examples } \\
\text { Company. }\end{array}$ \\
\hline $\begin{array}{l}\text { Similar } \\
\text { relationships }\end{array}$ & dcterms:created \\
\hline $\begin{array}{l}\text { Inverse } \\
\text { Relationship }\end{array}$ & Creator Relationship ID: 0022 \\
\hline
\end{tabular}

Table 3. Created_by X creator relationships.

\begin{tabular}{|l|l|}
\hline \multicolumn{2}{|l|}{ Design_or_procedure_for relationship } \\
\hline Relationship ID: 0031 \\
\hline Label & $\begin{array}{l}\text { "Design_or_Procedure_for"@en, } \\
\text { "Projeto_ou_esboço_para"@pt, } \\
\text { "Proyecto_o_esbozo_para"@es }\end{array}$ \\
\hline URI & $\begin{array}{l}\text { http://culturally_relevant_relationships.or } \\
\text { g/0021/ }\end{array}$ \\
\hline Description & $\begin{array}{l}\text { Relationships between architectural plans } \\
\text { (aHO) and a monument (monHO): cell } \\
14 ; \text { between an artwork (mHO) and their } \\
\text { preparatory sketches (mHO): cell thirty- } \\
\text { three. }\end{array}$ \\
\hline Domain & HO \\
\hline Range & HO \\
\hline Criteria & CD \\
\hline Examples & $\begin{array}{l}\text { The architectural plans of MAC } \\
\text { Niterói-Museum of Contemporary } \\
\text { Art-and the monument itself; the } \\
\text { preparatory sketches and Guernica by } \\
\text { Pablo Picasso; the preparatory sketches } \\
\text { and the "War and Peace" panels by } \\
\text { Brazilian artist Candido Portinari at the } \\
\text { United Nations headquarters, New York. }\end{array}$ \\
\hline $\begin{array}{l}\text { Similar } \\
\text { relationships }\end{array}$ & $\begin{array}{l}\text { Design_or_procedure, Relationship ID: } \\
\text { Inverse } \\
\text { Relationship }\end{array}$ \\
\hline
\end{tabular}

Table 4. Design_or_procedure_for X design_or_procedure relationships.

\begin{tabular}{|l|l|}
\hline \multicolumn{2}{|l|}{ Documents relationship } \\
\hline Relationship ID: 0041 \\
\hline Label & $\begin{array}{l}\text { "Documents”@en, “Documenta”@pt, } \\
\text { "Documento"@es }\end{array}$ \\
\hline URI & $\begin{array}{l}\text { http://culturally_relevant_relationships.org } \\
\text { /0031/ }\end{array}$ \\
\hline Description & $\begin{array}{l}\text { The relationship between a field notebook } \\
\text { and the objects it documents. }\end{array}$ \\
\hline Domain & $\begin{array}{l}\text { HO, with the type of expression form } \\
\text { text_object }\end{array}$ \\
\hline
\end{tabular}


C. H. Marcondes. Towards a Vocabulary to ImplementCulturally Relevant Relationships ...

\begin{tabular}{|l|l|}
\hline \multicolumn{2}{|l|}{ Documents relationship } \\
\hline Relationship ID: 0041 \\
\hline Range & HO, any type \\
\hline Criteria & $\begin{array}{l}\text { CI; the domain HO always has the type of } \\
\text { expression form text_object. }\end{array}$ \\
\hline Examples & $\begin{array}{l}\text { Darwin's Beagle's expedition field notebook } \\
\text { and the species collected by him. }\end{array}$ \\
\hline $\begin{array}{l}\text { Similar } \\
\text { relationships }\end{array}$ & crm:P70 documents (is documented in) \\
\hline $\begin{array}{l}\text { Inverse } \\
\text { Relationship }\end{array}$ & Documented_by, Relationship ID: 0042 \\
\hline
\end{tabular}

Table 5. Documents X documented_by relationships.

\begin{tabular}{|l|l|}
\hline Has_contribution_of relationship \\
\hline Relationship ID: 0051 \\
\hline Label & $\begin{array}{l}\text { "Has_theContribution_of"@en, } \\
\text { "Teve_Contribuição_de"@pt, } \\
\text { "haTenido_laContribuición_de"@es }\end{array}$ \\
\hline URI & $\begin{array}{l}\text { http://culturally_relevant_relationships.org/ } \\
\text { 0051/ }\end{array}$ \\
\hline Description & $\begin{array}{l}\text { The relationship between an intellectual, } \\
\text { artistic, or technical work embodied in a HO } \\
\text { and an agent, other than its creator, that } \\
\text { made some contribution to its realization, or } \\
\text { production; for example, the translator, } \\
\text { compiler or organizer of a work. }\end{array}$ \\
\hline Domain & HO \\
\hline Range & Agent \\
\hline Criteria & $\begin{array}{l}\text { Brazilian edition of the Hamlet by L\&PM } \\
\text { Editor Has_theContribution_of Millôr } \\
\text { Fernandes as the translator. The Anthology } \\
\text { of Medieval Literature } \\
\text { Has_theContribution_of Rebecca Berg } \\
\text { Manor as editor. } \\
\text { Anthology of Medieval Literature. Rebecca } \\
\text { Berg Manor (ed). Beautiful Feet Books, } \\
\text { 2013. } \\
\text { The Baptism of Christ by Andrea del } \\
\text { Verrocchio, painting that belongs to the } \\
\text { Uffizi Gallery Collection in Florence } \\
\text { Has_theContribution of Leonardo Da } \\
\text { Vinci; according to some art historians } \\
\text { Leonardo painted the angel on the left of } \\
\text { the picture }\end{array}$ \\
relationships \\
Inverse \\
Relationship
\end{tabular} \begin{tabular}{l} 
Contributor, Relationship ID: 0052 \\
\hline
\end{tabular}

Table 6. Has_theContribution_of X contributor relationships.

\begin{tabular}{|l|l|}
\hline \multicolumn{2}{|l|}{ Has_subject relationship } \\
\hline Relationship ID: 0061 \\
\hline Label & $\begin{array}{l}\text { "Has_Subject”@en, “Tem_Assunto”@pt, } \\
\text { "Tiene_asunto"@es }\end{array}$ \\
\hline URI & $\begin{array}{l}\text { http://culturally_relevant_relationships.org/ } \\
0041 /\end{array}$ \\
\hline Description & $\begin{array}{l}\text { Relationships between a book that has } \\
\text { letters as a subject; between a book that has } \\
\text { another book as a subject; between a book } \\
\text { that has a monument as a subject; between a } \\
\text { letter commenting on or describing a book } \\
\text { and the book itself; between a letter }\end{array}$ \\
\hline
\end{tabular}

\begin{tabular}{|l|l|}
\hline Has_subject relationship \\
\hline Relationship ID: 0061 \\
\hline Domain & $\begin{array}{l}\text { commenting or describing an artwork and } \\
\text { the artwork itself; between a book, a } \\
\text { biography of a historical character (range } \\
\text { agent). }\end{array}$ \\
\hline Range & $\begin{array}{l}\text { HO entity having the type of expression } \\
\text { form text_object }\end{array}$ \\
\hline Criteria & HO, any external entitie \\
\hline Examples & $\begin{array}{l}\text { La Joconde : essai scientifique / sous la } \\
\text { direction de Christian Lahanier, as many } \\
\text { other books, has as a subject, or describes, } \\
\text { or analyses, Da Vinci's Mona Lisa; a letter } \\
\text { from Brazilian writer Machado de Assis to } \\
\text { his colleague Joaquim Nabuco commenting } \\
\text { on the idea for a future book, Ayres Memorial } \\
\text { (Jackson 1998); the book Brunelleschi's Dome: } \\
\text { The Story of the Great Cathedral in Florence } \\
\text { (King, 2008) has as subject the construction } \\
\text { of Brunelleschi's Dome of Santa Maria del } \\
\text { Fiori church; the book Napoleon: a life, by } \\
\text { Andrew Roberts (2015). }\end{array}$ \\
\hline $\begin{array}{l}\text { Similar } \\
\text { relationships }\end{array}$ & \begin{tabular}{l} 
Is_subject_of, Relationship ID: 0062 \\
\hline $\begin{array}{l}\text { Inverse } \\
\text { Relationship }\end{array}$
\end{tabular} \\
\hline
\end{tabular}

Table 7. Has_subject X is_subject_of relationships.

\begin{tabular}{|l|l|}
\hline \multicolumn{2}{|l|}{ Influenced relationship } \\
\hline Relationship ID: 0071 \\
\hline Label & $\begin{array}{l}\text { "Influenced"@en, "Influenciou"@pt, } \\
\text { "Influenciado"@es }\end{array}$ \\
\hline URI & $\begin{array}{l}\text { http://culturally_relevant_relationships.org } \\
\text { /0051/ }\end{array}$ \\
\hline Description & $\begin{array}{l}\text { Relationships between a work that } \\
\text { influenced the creation of another work, } \\
\text { according to someone. Or, the relationship } \\
\text { between a work and the agent_artist, } \\
\text { writer_that influenced it. This relationship } \\
\text { is assigned by someone, an art or literature } \\
\text { critic or historian. }\end{array}$ \\
\hline Domain & HO \\
\hline Range & HO, Agent \\
\hline Criteria & CA, EI. \\
\hline Examples & $\begin{array}{l}\text { According to several literary critics, the } \\
\text { work Don Quijote by Cervantes Saavedra } \\
\text { influenced many others literary works; or } \\
\text { the "List of works influenced by One } \\
\text { Thousand and One Nights"; and "How Did } \\
\text { Edgar Allan Poe Influence Literature"? One } \\
\text { of the two HO is intended for the other or } \\
\text { to an agent. }\end{array}$ \\
\hline $\begin{array}{l}\text { Similar } \\
\text { relationships } \\
\text { didbpedia.org/ontology:influencedBy }\end{array}$ \\
\hline $\begin{array}{l}\text { Inverse } \\
\text { Relationship }\end{array}$ & \begin{tabular}{l} 
Influenced_by, Relationship ID: 0072 \\
\hline
\end{tabular} \\
\hline
\end{tabular}

Table 8. Influenced X influenced_by relationships. 
1 The formalization of the "influenced" relationship is a challenging issue. Here we documented the relationships 3 of an HO that influenced other HOs, and an HO influenced_by an agent. It is usual in art and literature critics to 5 say that an author or artist influenced others, as such a c claim means that the works of an author or artist as a whole influenced the works of many others, as for exam8 ple in the exhibition Vermeer and the Masters of Genre Painting: Inspiration and Rivalry. The latter would be a relationship 0 between two agents, which is out of the scope of the rela1 tionships we are dealing with here. A cultural heritage 12 cloud will integrate cultural heritage collections published 13 as linked data with data hubs as Wikipedia, Wikidata (Wik14 idata:WikiProject Authority Control), DBpedia (Ester15 mann 2018) and authority control databases (Klein and 16 Kyrios 2013) such as VIAF (Agenjo-Bullón and Hernán17 dez-Carrascal 2018).

\begin{tabular}{|c|c|}
\hline \multicolumn{2}{|c|}{ Inspired relationship } \\
\hline \multicolumn{2}{|c|}{ Relationship ID: 0081} \\
\hline Label & $\begin{array}{l}\text { "Inspired”@en, “Inspirou”@pt, } \\
\text { "Inspirado"@es }\end{array}$ \\
\hline URI & $\begin{array}{l}\text { http://culturally_relevant_relationships.org } \\
\text { /0061/ }\end{array}$ \\
\hline Description & $\begin{array}{l}\text { Relationship between a book which inspired } \\
\text { a painting or drawing; between an artwork } \\
\text { and a book. Relationships between two } \\
\text { independent works with different authors. }\end{array}$ \\
\hline Domain & $\mathrm{HO}$ \\
\hline Range & $\mathrm{HO}$ \\
\hline Criteria & $\begin{array}{l}\text { CD; EI, both works may have the same or } \\
\text { different expressions forms but they must } \\
\text { have different authors. }\end{array}$ \\
\hline Examples & $\begin{array}{l}\text { Inspired is a loose relationship in } \\
\text { comparison to influenced or based_on. The } \\
\text { previously mentioned aquatint by Picasso } \\
\text { portraying Don Quijote and Sancho Panza } \\
\text { and the book Don Quijote de La Mancha by } \\
\text { Cervantes Saavedra; or the romance Iracema } \\
\text { by the Brazilian writer José de Alencar and a } \\
\text { painting with the same title by José Maria } \\
\text { Medeiros; or the Da Vinci's Mona Lisa and } \\
\text { the romance Mona Lisa Overdrive by William } \\
\text { Gibson (1997); or the romance Buenos Aires } \\
\text { Memorial by Antonio Fernando Borges } \\
\text { (2006) and the romance Aires Memorial by } \\
\text { Machado de Assis, among many others. }\end{array}$ \\
\hline $\begin{array}{l}\text { Similar } \\
\text { relationships }\end{array}$ & $\begin{array}{l}\text { wikim:inspired, LRM21:is inspiration for; } \\
\text { frbr:has a transformation/is a } \\
\text { transformation of }\end{array}$ \\
\hline $\begin{array}{l}\text { Inverse } \\
\text { Relationship }\end{array}$ & Inspired_by, Relationship ID: 0082 \\
\hline
\end{tabular}

Table 9. Inspired X inspired_by relationships.

\begin{tabular}{|l|l|}
\hline \multicolumn{2}{|l|}{ Is_illustrated_by relationship } \\
\hline Relationship ID: 0091 \\
\hline Label & $\begin{array}{l}\text { "Is_Illustrated_by"@en, } \\
\text { "É_Ilustrado_por"@pt, } \\
\text { "Es_Ilustrado_por"@es }\end{array}$ \\
\hline
\end{tabular}

\begin{tabular}{|l|l|}
\hline Is_illustrated_by relationship \\
\hline Relationship ID: 0091 \\
\hline URI & $\begin{array}{l}\text { http://culturally_relevant_relationships.or } \\
\text { g/0071/ }\end{array}$ \\
\hline Description & $\begin{array}{l}\text { Relationship: between a book that is } \\
\text { illustrated by a painting or drawing, or } \\
\text { between a book that is illustrated by an } \\
\text { agent }\end{array}$ \\
\hline Domain & HO, type of expression form text_objects \\
\hline Range & $\begin{array}{l}\text { HO, type of expression form must be } \\
\text { two_dimensional objects }\end{array}$ \\
\hline Criteria & $\begin{array}{l}\text { CD, ED, domain lHO has the expression } \\
\text { form text objects, range mHO has the } \\
\text { expression form iconographic, } \\
\text { two_dimensional objects }\end{array}$ \\
\hline Examples & $\begin{array}{l}\text { Aristophanes' Lysitrata (1934), edited by } \\
\text { the Limited Editions Club, which is } \\
\text { illustrated by six signed etchings of Pablo } \\
\text { Picasso; James Joyce's Ulysses (1999), } \\
\text { edition illustrated by Henri Matisse's rare } \\
\text { etchings. }\end{array}$ \\
\hline $\begin{array}{l}\text { Similar } \\
\text { relationships }\end{array}$ & $\begin{array}{l}\text { Illustrated, Relationship ID: 0092 } \\
\text { Relationship }\end{array}$ \\
\hline
\end{tabular}

Table 10. Is_illustrated_by X illustrated relationships.

\begin{tabular}{|l|l|}
\hline \multicolumn{2}{|l|}{ Link_to_Agent relationship } \\
\hline Relationship ID: 0101 \\
\hline Label & $\begin{array}{l}\text { "Link_to_Agent"@en, } \\
\text { "Vinculação_a_Pessoa"@pt, } \\
\text { "Vinculación_a_la_persona"@es }\end{array}$ \\
\hline URI & $\begin{array}{l}\text { http://culturally_relevant_relationships.org } \\
\text { /0081/ }\end{array}$ \\
\hline Description & $\begin{array}{l}\text { The relationship between a HO and an } \\
\text { agent that this HO belonged, used or has } \\
\text { some kind of relationship }\end{array}$ \\
\hline Domain & HO \\
\hline Range & Agent \\
\hline Criteria & CA \\
\hline Examples & $\begin{array}{l}\text { The HMS Victory was the flagship of } \\
\text { Admiral Nelson at "Battle of Trafalgar" on } \\
\text { 21 October 1805. }\end{array}$ \\
\hline $\begin{array}{l}\text { Similar } \\
\text { relationships }\end{array}$ & edm:HasMet \\
\hline $\begin{array}{l}\text { Inverse } \\
\text { Relationship }\end{array}$ & $\begin{array}{l}\text { Link_agent_to_object, Relationship ID: } \\
\text { 0102 }\end{array}$ \\
\hline
\end{tabular}

Table 11. Link_to_agent X Link_agent_to_object relationships.

\begin{tabular}{|l|l|}
\hline \multicolumn{2}{|l|}{ Link_to_event_process relationship } \\
\hline Relationship ID: 0121 \\
\hline Label & $\begin{array}{l}\text { "Link_to_Event_Process"@en, } \\
\text { "Vinculação_a_Evento_Processo"@pt, } \\
\text { "Vinculación_a_Evento_Proceso"@es }\end{array}$ \\
\hline URI & $\begin{array}{l}\text { http://culturally_relevant_relationships.org } \\
/ 0091 /\end{array}$ \\
\hline Description & $\begin{array}{l}\text { The relationship between a HO and an } \\
\text { event or process in which this HO was } \\
\text { present or has some kind of relationship }\end{array}$ \\
\hline Domain & HOs \\
\hline Range & Event_process \\
\hline Criteria & CA \\
\hline
\end{tabular}


C. H. Marcondes. Towards a Vocabulary to ImplementCulturally Relevant Relationships ...

\begin{tabular}{|l|l|}
\hline \multicolumn{2}{|l|}{ Link_to_event_process relationship } \\
\hline Relationship ID: 0121 \\
\hline Examples & $\begin{array}{l}\text { The HMS Victory ship and the Battle of } \\
\text { Trafalgar on 21 October 1805. }\end{array}$ \\
\hline $\begin{array}{l}\text { Similar } \\
\text { relationships }\end{array}$ & $\begin{array}{r}\text { crm: P12 occurred in the presence of (was } \\
\text { present at), edm:HasMet }\end{array}$ \\
\hline $\begin{array}{l}\text { Inverse } \\
\text { Relationship }\end{array}$ & $\begin{array}{l}\text { Link_event_process_to_object, } \\
\text { Relationship ID: 0122 }\end{array}$ \\
\hline
\end{tabular}

Table 12. Link_to_event_process X Link_event_process_to_ object relationships.

\begin{tabular}{|c|c|}
\hline \multicolumn{2}{|c|}{ Mentioned_in relationship } \\
\hline \multicolumn{2}{|c|}{ Relationship ID: 0131} \\
\hline Label & $\begin{array}{l}\text { "Mentioned_in"@en, } \\
\text { "Mencionado_em”@pt, } \\
\text { "Mencionado_en"@es }\end{array}$ \\
\hline URI & $\begin{array}{l}\text { http://culturally_relevant_relationships.org } \\
\text { /0111/ }\end{array}$ \\
\hline Description & $\begin{array}{l}\text { This is the usual relationship between a HO } \\
\text { that is mentioned in a document-a letter, } \\
\text { an inventory, an exhibition catalog or a } \\
\text { book. }\end{array}$ \\
\hline Domain & $\mathrm{HO}$ \\
\hline Range & $\mathrm{HO}$, Expression form is text_objects \\
\hline Criteria & CI, EI \\
\hline Examples & $\begin{array}{l}\text { A letter (602) from Vincent Van Gogh } \\
\text { (1888) to his brother Theo, Arles, Tuesday, } \\
1 \text { May } 1888, \text { mentioning a drawing "Public } \\
\text { garden and pond in front of the Yellow } \\
\text { House." } \\
\text { The painting "The Prodigal Son in the } \\
\text { Tavern" by Rembrandt is mentioned in the } \\
\text { Rembrandt catalog raisonné, by Christian } \\
\text { and Astrid Tümpel (1986). }\end{array}$ \\
\hline $\begin{array}{l}\text { Similar } \\
\text { relationships }\end{array}$ & dcterms:isReferencedBy \\
\hline $\begin{array}{l}\text { Inverse } \\
\text { Relationship }\end{array}$ & Mentioned, relationship id: 0132 \\
\hline
\end{tabular}

Table 13. Mentioned_in X mentioned relationships.

\begin{tabular}{|l|l|}
\hline Part_of relationship \\
\hline Relationship ID: 0141 \\
\hline Label & $\begin{array}{l}\text { "Part_of"@en, "Parte_de"@pt, } \\
\text { "Parte_de"@es }\end{array}$ \\
\hline URI & $\begin{array}{l}\text { http://culturally_relevant_relationships.org } \\
/ 0111 /\end{array}$ \\
\hline Description & $\begin{array}{l}\text { The relationship between a HO that is a } \\
\text { part or a fragment of another HO. }\end{array}$ \\
\hline Domain & $\begin{array}{l}\text { HO, both having the same type of } \\
\text { expression form }\end{array}$ \\
\hline Range & HO \\
\hline Criteria & CD \\
\hline Examples & $\begin{array}{l}\text { The angel playing an organ is part_of the } \\
\text { Van Eyck's Ghent Altarpiece, housed in the } \\
\text { Cathedral of St. Bavo, Ghent, Belgium. }\end{array}$ \\
\hline $\begin{array}{l}\text { Similar } \\
\text { relationships }\end{array}$ & $\begin{array}{l}\text { The crm:P5 consists of (forms part of), } \\
\text { dc:isPartOf, }\end{array}$ \\
\hline $\begin{array}{l}\text { Inverse } \\
\text { Relationship }\end{array}$ & Has_part, Relationship ID: 0142 \\
\hline
\end{tabular}

Table 14. Part_of X has_part relationships.

\begin{tabular}{|l|l|}
\hline \multicolumn{2}{|l|}{ Portrays relationship } \\
\hline Relationship ID:0151 \\
\hline Label & $\begin{array}{l}\text { "Portrays"@en, “Retrata"@pt, } \\
\text { "Retrata"@es }\end{array}$ \\
\hline URI & $\begin{array}{l}\text { http://culturally_relevant_relationships.org } \\
/ 0121 /\end{array}$ \\
\hline Description & $\begin{array}{l}\text { The relationship between a HO and another } \\
\text { HO, agent, event_process or place that HO } \\
\text { portrays. }\end{array}$ \\
\hline Domain & $\begin{array}{l}\text { HO, type of expression form } \\
\text { two_dimensional objects }\end{array}$ \\
\hline Range & HO, agent, event_process, place \\
\hline Criteria & CD \\
\hline Examples & $\begin{array}{l}\text { Several paintings made by French } \\
\text { impressionist artist Monet portraying the } \\
\text { Rouen Cathedral. The Louvre Museum has } \\
\text { a portrait of Napoleon Bonaparte painted } \\
\text { by Antonine Jean Gros. }\end{array}$ \\
\hline $\begin{array}{l}\text { Similar } \\
\text { relationships } \\
\text { edm:hasView }\end{array}$ \\
\hline $\begin{array}{l}\text { Inverse } \\
\text { Relationship }\end{array}$ & Is_portrayed_by, Relationship ID: 0152 \\
\hline
\end{tabular}

Table 15. Portrays X is_portrayed_by relationships.

\begin{tabular}{|l|l|}
\hline \multicolumn{2}{|l|}{ Provenance relationship } \\
\hline Relationship ID: 0161 \\
\hline Label & $\begin{array}{l}\text { "Provenance"@en, "Proveniência"@pt, } \\
\text { "Procedencia"@es }\end{array}$ \\
\hline URI & $\begin{array}{l}\text { http://culturally_relevant_relationships.org } \\
/ 0131 /\end{array}$ \\
\hline Description & $\begin{array}{l}\text { The relationship between a HO and its } \\
\text { place of creation }\end{array}$ \\
\hline Domain & HO, any \\
\hline Range & Place \\
\hline Criteria & CA \\
\hline Examples & $\begin{array}{l}\text { The mask of Tutankhamun, now at the } \\
\text { Egyptian Museum of Cairo, and Valley of } \\
\text { the Kings, Egypt, where it was discovered. } \\
\text { Duplicate objects or donations sent from an } \\
\text { institution to another }\end{array}$ \\
\hline $\begin{array}{l}\text { Similar } \\
\text { relationships }\end{array}$ & dcterms:provenance \\
\hline $\begin{array}{l}\text { Inverse } \\
\text { Relationship }\end{array}$ & $\begin{array}{l}\text { Place_of_provenance, Relationship ID: } \\
\text { 0162 }\end{array}$ \\
\hline
\end{tabular}

Table 16. Provenance X place_of_provenance relationships.

\begin{tabular}{|l|l|}
\hline \multicolumn{2}{|l|}{ Similar_item relationship } \\
\hline Relationship ID: 0171 \\
\hline Label & $\begin{array}{l}\text { "Similar_item"@en, “Item_similar"@pt, } \\
\text { "item_relacionado"@es }\end{array}$ \\
\hline URI & $\begin{array}{l}\text { http://culturally_relevant_relationships.org } \\
/ 0141 /\end{array}$ \\
\hline Description & $\begin{array}{l}\text { The relationship between similar items, } \\
\text { according to a collection curator }\end{array}$ \\
\hline Domain & $\begin{array}{l}\text { HO, both domain and range have the same } \\
\text { type of expression form }\end{array}$ \\
\hline Range & HO \\
\hline Criteria & CA, IS \\
\hline Examples & $\begin{array}{l}\text { Similar items, as in museums in Israel. } \\
\text { Greek pottery from Greece and from south } \\
\text { Italy. }\end{array}$ \\
\hline
\end{tabular}


C. H. Marcondes. Towards a Vocabulary to ImplementCulturally Relevant Relationships ...

\begin{tabular}{|l|l|}
\hline \multicolumn{2}{|l|}{ Similar_item relationship } \\
\hline Relationship ID: 0171 \\
\hline $\begin{array}{l}\text { Similar } \\
\text { relationships }\end{array}$ & \\
\hline $\begin{array}{l}\text { Inverse } \\
\text { Relationship }\end{array}$ & The relationship is symmetric \\
\hline
\end{tabular}

Table 17. Similar_item relationship.

1 A synthesis of the relationships proposed follows.

\begin{tabular}{|l|l|}
\hline \multicolumn{1}{|c|}{ RELATIONSHIP } & \multicolumn{1}{c|}{$\begin{array}{c}\text { INVERSE } \\
\text { RELATIONSHIP }\end{array}$} \\
\hline Id: 0011 Based_on & Id: 0012 Base_for \\
\hline Id: 0021 Created_by & Id: 0022 Creator \\
\hline $\begin{array}{c}\text { Id: 0031 } \\
\text { Design_or_Procedure } \\
\text { for }\end{array}$ & $\begin{array}{l}\text { Id: } 0032 \\
\text { Design_or_Procedure }\end{array}$ \\
\hline Id: 0041 Documents & Id: 0042 Documented_by \\
\hline $\begin{array}{l}\text { Id: 0051 } \\
\text { Has_Contribution_of }\end{array}$ & Id: 0052 Contributor \\
\hline Id: 061 Has_Subject & Id: 0062 Has_Subject \\
\hline Id: 0071 Influenced & Id: 0072 Influenced_by \\
\hline Id: 081 Inspired & Id: 0082 Inspired_by \\
\hline Id: 0091 Is_Illustrated_by & Id: 092 Illustrated \\
\hline $\begin{array}{l}\text { Id:0101 Link_to_Agent } \\
\text { Id: 0121 }\end{array}$ & $\begin{array}{l}\text { Id: 0102 Link_Agent_to } \\
\text { Link_to_Ebject }\end{array}$ \\
\hline Id: 0131 Mentioned_in & Id: 0122 \\
\hline Id: 0141 Part_of & Link_Event_Process_to_ \\
\hline Id: 0151 Portrays & Object 0132 Mentioned \\
\hline Id: 0161 Provenance & Id: 0142 Has_part \\
\hline Id: 0171 Similar_item & Id: 0152 Is_Portrayed_by \\
\hline
\end{tabular}

Table 18. Synthesis of the relationships proposed.

7 As previously stated, the vocabulary of culturally relevant 8 relationships was conceived to be used by cultural curators, 9 even if a relationship is automatically generated from cat10 alog systems. A known limitation of the RDF triple model 11 is the lack of provenance information. In the case of the 12 vocabulary of culturally relevant relationships, provenance 13 information is the identification of the curator or the in14 stitution that proposed/assigned a culturally relevant rela15 tionship between two digital HOs, whether manually or 16 automatically assigned.
2014). One of such proposals is Named Graphs (Carroll et al. 2005). Among others, the authors propose a semantic web publishing vocabulary with entities as graph, warrant, and authority, aimed at extending the RDF model to ensure warranty and authority of a statement. Any implementation of the proposed vocabulary may consider and combine such extensions of the RDF model. We propose using such technologies to assign provenance to culturally relevant relationships. Here follows an example of the assignment of provenance information to a culturally relevant relationship realized as a named graph (the example is coded in TriG format (Carroll et al. 2005).

(a) prefix dc: $<$ http://purl.org/dc $>$.

@prefix crr: < http://culturaly_relevant_relationships.org/ $>$

(a)prefix foaf: <http://xmlns.com/foaf/0.1/>. :r1 $=\{$ :http://datos.bne.es/obra/XX3383563 crr:Inspired :https://www.moma.org/collection/works/68157 \} :r1.1 = \{ :r1 dc:creator orcid: <https://orcid.org/0000-

0003-0929-8475>

:r1 dc:date :'20190417”\}

:r1.1.1 = : :r1.1 foaf:name:" Marcondes"

:r1.1 foaf:mbox :<mailto: ch_marcondes@id.uff.br>

:r1.1 foaf:homepage $:<$ http://www.professores.uff.br/ $\underline{\text { marcondes }}>$ \}

\subsection{Concluding remarks}

Regarding the HO-agents relationships, we opt to use relationship labels that express their semantics as clearly as possible, such as compiled_by, created_by, is_illustratedby, instead of using created_by and a possible "Has_theContribution_of/Contributor" relationship as in the Dublin Core vocabulary; this last relationship does not express clearly the role of the agent as a contributor with respect to the HO. As previously stated, the proposed vocabulary of culturally relevant relationships is conceived to be used by cultural curators for annotating resources, so a clear semantic is an important prerequisite.

In this paper, a vocabulary of culturally relevant relationships is proposed between heritage objects (their digital surrogate: metadata, digital text and/or images) comprising heritage institutions collections. Such a vocabulary may be implemented using LOD technologies. The intended users of such a vocabulary are curators, cultural or literary critics, or scholars, in creating novel digital resources based on their authorial annotations. Such annotations comply with standards as the Open Annotation Data Model (http:/ /www.openannotation.org/spec/core/). 
C. H. Marcondes. Towards a Vocabulary to ImplementCulturally Relevant Relationships ...

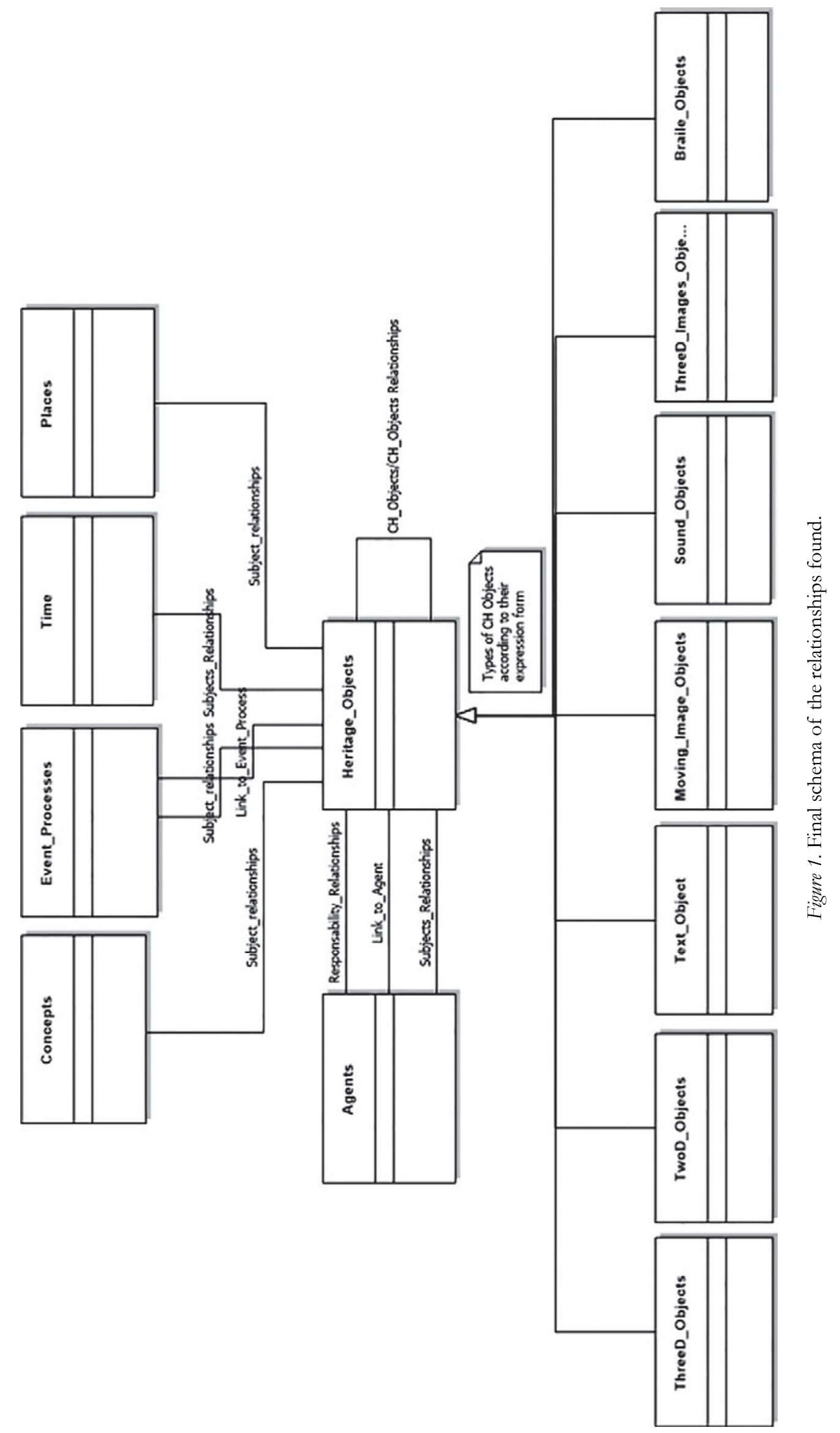


We envision as a possibility the use of the vocabulary of culturally relevant relationships as a web portal hosting LOD datasets of collections of several different heritage institutions. Through this web portal, curators can crosssearch collections for culturally relevant objects, agents, subjects, events or periods of time, and places. Once they find what they consider a culturally relevant relationship between two entities, they can propose/assign such a relationship from the vocabulary. A curator can also save a set of such relationships as an authorial trajectory or roadmap to these collections, creating a virtual exhibition. Users can navigate through virtual exhibitions; heritage institutions can also enrich their LOD datasets with the relationships proposed by curators. The annotation of digital objects can be used as a target resource for enrichment processes of heritage collections (Europeana 2015).

The publishing of digital collections over the web opens new opportunities to heritage institutions. It enhances access, enables reuse, and achieves full integration of collections to the mainstream web, thus enlarging their reach and synergies. Such synergies can be exploited as culturally relevant relationships are established between the digital objects of these collections implemented as LOD links. The contribution of this article is to propose a vocabulary of culturally relevant relationships to provide semantics to such links. The interlinking of resources from different institutions provides rich contexts not available by OPAC technologies. The reciprocal implementation of LOD links between heterogeneous and distributed digital collections requires cooperation, coordination, and curatorial activities on a new level. It can also achieve interoperability, improve synergies and usability between collections, thus empowering and reshaping heritage institutions. This is ongoing research; the results presented and the schema proposed herein are provisional and a starting point to be discussed, tested, and enhanced.

A limitation of this research is that the relationships proposed are not yet validated as a whole as a vocabulary to be used by cultural curator in annotating digital heritage objects published as LOD. A next step is to create complex use cases and submit them to evaluation. An example of such a use case is "Botticelli 92 drawings" (that belongs to the collections of the Kupferstichkabinett Berlin and the Vatican Library) illustrating the Dante's Divine Comedy (see also the 1481 printed edition) which were commissioned by Lorenzo de Medici (which contract is in the collection of the Archivio di Stato di Firenze) (Watts 1995).

\section{Note}

1. Example suggested by Ram Shimony

\section{References}

Agenjo-Bullón, Xavier. 2015. "Bibliotecas Virtuales en 2014, Año de Consolidación del Modelo Linked Open Data." Anuário ThinkEPI 2015: 9-21. https://recyt. fecyt.es/index.php/ThinkEPI/article/view/info.2015. 02

Agenjo-Bullón, Xavier and Hernández-Carrascal Francisca. 2018. "Registros de Autoridades, Enriquecimiento Semántico y Wikidata.” AnuarioThink EPI 12: 361-72.

Alencar, José de. Iracema: Legend of Ceará. 1865. Rio de Janeiro: Typographia de Vianna \& Filhos.

ANSI-NISO. 2005. "ANSI-NISO Z39-19: Guidelines for the Construction, Format and Management of Monolingual Controlled Vocabularies." Bethesda, MD: ANSI/ NISO.

Berners-Lee, Tim. 2006. "Linked Data." W3C. https:// www.w3.org/DesignIssues/LinkedData .html

Carroll, Jeremy J., Bizer Christian, Hayes Pat and Patrick Stickler. 2005. "Named Graphs." Web Semantics: Science, Services and Agents on the World Wide Web 3, no.4: 247-67.

CIDOC Conceptual Reference Model Version 5.1.12. 2014. ICOM/CIDOC. http://www.cidoc-crm.org/Version/ version-5.1.2

Constantopoulos, Panos and Dallas Costis. 2008. "Aspects of a Digital Curation Agenda for Cultural Heritage," In 2008 IEEE International Conference on Distributed HumanMachine Systems. Athens, Greece: IEEE, 1-6.

Dahlberg, Ingetraut. 1992. "Knowledge Organization and Terminology: Philosophical and Linguistic bases," International Classification 19: 65-71.

Erxleben, Fredo, et al. 2014. "Introducing Wikidata to the Linked Data Web.” In International Semantic Web Conference. Cham, Switzerland: Springer, 50-65.

Estermann, Beat. 2018. "How Wikidata is Solving its Chicken-or-Egg-Problem in the Field of Cultural Heritage." SocietyByte. https://www.societybyte.swiss/2018/ 11/07/how-wikidata-is-solving-its-chicken-or-egg-prob lem-in-the-field-of-cultural-heritage/

Europeana Task Force on Enrichment and Evaluation. 2015. “Report on Enrichment and Evaluation.” https:// pro.europeana.eu/files/Europeana_Professional/Euro peanaTech/EuropeanaTech_taskforces/Enrichment_ Evaluation/FinalReport_EnrichmentEvaluation_102015 .pdf

Europeana. 2017. "Definition of Europeana Data Model Version 5.2.7.” https://pro.europeana.eu/files/Europea na_Professional/Share_your_data/Technical_require ments/EDM_Documentation/EDM_Definition_v5. 2.8_102017.pdf

EuroVoc Thesaurus.2015. Volume 1 Alphabetical Version Part B. Edition 4.4/English Language. Luxembourg: Publications Office of the European Union. 
C. H. Marcondes. Towards a Vocabulary to ImplementCulturally Relevant Relationships ...

Farradane, Jason. 1980. "Relational Indexing. Part I." Journal of Information Science1, no. 5: 267-76.

Gandon, Fabien and Corby Olivier. 2010. "Name that Graph or the Need to Provide a Model and Syntax Extension to Specify the Provenance of RDF Graphs." In W3C Workshop - RDF Next Steps Getty Vocabularies as LOD.

Green, Rebecca. 2008. "Relationships in Knowledge Organization.” Knowledge Organization35: 150-59.

Guarino, Nicola. 1997. "Some Organizing Principles for a Unified Top-level Ontology.” In AAAI Spring Symposium on Ontological Engineering. Menlo Park: AAAI Press, 57-63.

Guarino, Nicola and Christopher Welty. 2000a. "A Formal Ontology of Properties." In Knowledge Engineering and Knowledge Management Methods, Models and Tools, 12th International Conference, EKAW 2000. LNCS 1937. [Berlin]: Springer, 97-112.

Guarino, Nicola and Christopher A. Welty. 2000b. "An Overview of OntoClean." In Handbook on Ontologies. Berlin: Springer, 201-20.

Hessen, Johannes. 2000. Theory of Knowledge. São Paulo: Martins Fontes.

International Council on Archives. Experts Group on Archival Description. 2016. Records in Context: A Conceptual Model for Archival Description (Consultation Draft v0.1). ICA. http://www.ica.org/sites/default/files/RiC-CM0.1.pdf, accessed December 12.

International Federation of Library Associations and Institutions (IFLA). 1997. Study Group on Functional Requirements for Bibliographic Records: Final Report. UBCIM Publications New Series. München: K. G. Saur.

Klein, Maximilian and Alex Kyrios. 2013. "VIAFbot and the Integration of Library Data on Wikipedia." Code4Lib 2: 85-107.

Khoo, Christopher S. G. and Na Jin-Cheon. 2006. "Semantic Relations in Information Science," Annual Review of Information Science and Technology 40, no.1: 157-228.

Library of Congress. 2016. BIBFRAME: Bibliographic Framework Initiative. https://www.loc.gov/bibframe/

Marcondes, Carlos H. 2018a. "Culturally Relevant Relationships: Publishing and Connecting Digital Objects in Collections of Archives, Libraries and Museums over the Web." In Challenges and Opportunities for Knowledge Organization in the Digital Age, Proceedings of the 15th International ISKO Conference July 2018, Porto, Portugal, ed. Maria Elisa Cerveira. Advances in Knowledge Organization 16. Würzburg: Ergon Verlag, 538-49.

Marcondes, Carlos H. 2018b. Open Linked Data of Archives, Libraries and Museums over the Web. EPI Scholar. Barcelona: Editorial UOC.

Marcondes, Carlos H. 2018c. "Culturally Relevant Relationships to Interconnect Digital Heritage Objects on The Web Using Linked Data Technologies." In Proceedings of the 19th ENANCIB, Londrina, Brazil. Londrina: UEL/ANCIB. http://enancib.marilia.unesp.br/index. $\mathrm{php} / \mathrm{XIXENANCIB/xixenancib/schedConf/presen}$ tations

Marcondes, Carlos. H. 2019. "A Classification of Types of Heritage Objects for The Integration of Digital Archives, Libraries and Museums." Scire 25, no. 2: 45-52. https://www.ibersid.eu/ojs/index.php/scire/article/ view $/ 4618$

Marcondes, Carlos H. and Campos Maria Luiza de Alemida. 2016. "Searching for a Methodology to Define Culturally Relevant Relationships between Digital Collections in Archives, Libraries and Museums." In Knowledge Organization for a Sustainable World: Challenges and Perspectives for Cultural, Scientific and Technological Sharing in a Connected Society: Proceedings of the $14^{\text {th }}$ International ISKO Conference, eds. José Augusto Chaves Guimarães, Suellen Oliveira Milani and Vera Dodebei. Advances in Knowledge Organization 15. Würzburg: Ergon Verlag, 493-501.

Peters, Isabella and Katrin Weller. 2008. "Paradigmatic and Syntagmatic Relations in Knowledge Organization Systems." Information Wissenschaft und Praxis 59, no.2: 100107.

Joint Steering Committee for Development of RDA. 2015. "RDA: Resource Description and Access." http:// www.rda-jsc.org/archivedsite/rda.html

Resource Description Framework (RDF). 2014. W3C. https://www.w3.org/RDF/

Riva, Pat, Patrick Le Boeuf and Žumer Maja. 2017. IFLA Library Reference Model: A Conceptual Model for Bibliographic Information. https://www.ifla.org/files/assets/catalogui ng/frbr-lrm/ifla-lrm-august-2017_rev201712.pdf

Searle, John. 1995. The Construction of Social Reality. New York: Free Press.

Tillett, Barbara B. 2001. "Bibliographic Relationships.” In Relationships in the Organization of Knowledge, ed. Carol A. Bean and Rebecca Green. Dordrecht: Kluwer Academic Publishers, 19-35.

Van Mensch, Peter. 1992. Toward a Methodology of Museology. PhD diss., University of Zagreb. http://emuzeum.cz/ admin/files/Peter-van-Mensch-disertace.pd.

W3C Incubator Group. 2011. Library Linked Data Incubator Group Final Report. W3C. http://www.w3.org/2005/ Incubator/lld/XGR-lld-20111025/

Watts, Barbar J. 1995. "Sandro Botticelli's Drawings for Dante's Inferno: Narrative Structure, Topography and Manuscript Design.” Artibus et Historiae, 163-201.

Wikidata. 2019. Project Authority Control. https://www. wikidata.org/wiki/Q9605193

Zeng, Marcia Lei. 2005. Construction of Controlled Vocabularies: A Primer (based on Z39.19). NISO. http://marciazeng. slis.kent.edu/Z3919/index.htm. 
Zeng, Marcia Lei. 2018. "Interoperability Approaches in KOS Vocabulary Development Observable Changes in the LOD-enabled Mashup Culture." In NKOS 2018, Proceedings of the DCMI Conference, Porto, Portugal, 13 Sept.
7 Zeng, Marcia Lei. 2019. “Interoperability.” Knowledge Organ8 iration 46: 122-46.

\section{Appendix 1. Examples of use cases collected}

\begin{tabular}{|c|c|c|}
\hline \multicolumn{3}{|l|}{ Description of the USE CASE } \\
\hline Suggested by: Angela Bittencourt & \multicolumn{2}{|l|}{ Institution: BN } \\
\hline \multirow{2}{*}{\multicolumn{3}{|c|}{$\begin{array}{l}\text { The painting Iracema by the artist José Maria de Medeiros, dated 1881, part of the collection of the National Museum of } \\
\text { Fine Arts in Rio de Janeiro, was inspired by the novel of the same name by José de Alencar, first published in 1865, } \\
\text { which has several copies in the collection of the National Library. } \\
\text { RELATION/INVERSE RELATION }\end{array}$}} \\
\hline & & \\
\hline $\begin{array}{l}\text { Painting "Iracema," by the artist José Maria de } \\
\text { Medeiros, } 1881\end{array}$ & $\begin{array}{l}\text { WAS INSPIRED BY -> } \\
<- \text { INSPIRED }\end{array}$ & $\begin{array}{l}\text { Novel "Iracema," by José de Alencar, } \\
1865\end{array}$ \\
\hline National Fine Arts Museum Collection & & National Library of Brazil Collection \\
\hline
\end{tabular}

\begin{tabular}{|c|c|c|}
\hline \multicolumn{3}{|l|}{ Description of the USE CASE } \\
\hline Suggested by: $\quad$ Elenora Machado & \multicolumn{2}{|c|}{ Institution: SMU/SEC-RJ } \\
\hline \multirow{2}{*}{\multicolumn{3}{|c|}{$\begin{array}{l}\text { The novel Dona Flor and her two busbands, by Jorge Amado, is illustrated with engravings by the artist Carybé } \\
\text { RELATION/INVERSE RELATION }\end{array}$}} \\
\hline & & \\
\hline $\begin{array}{l}\text { Novel Dona Flor and her two husbands, by Jorge } \\
\text { Amando }\end{array}$ & $\begin{array}{l}\text { IS ILLUSTRATED -> } \\
<- \text { ILLUSTRATE }\end{array}$ & Engravings by Carybé \\
\hline
\end{tabular}

\section{Appendix 2. Heritage Objects referenced}

"Battle of Trafalgar." Accessed September 2, 2019. https:// en.wikipedia.org/wiki/HMS_Victory.

"The Baptism of Christ." Accessed August 12, 2019. https://en.wikipedia.org/wiki/The_Baptism_of_ Christ_(Verrocchio_and_Leonardo).

Borges, Antonio Fernando. "Memorial de Buenos Aires." Accessed March 21, 2019. https://books.google. com.br/books/about/Memorial_de_Buenos_Aires. html?id=AsTuAAAAMAAJ\&source=kp_book_de scription\&redir_esc $=\mathrm{y}$.

Botero, Fernando. "Mona Lisa, Age Twelve" [painting]. Accessed September 2, 2019. https://www.moma.org/ collection/works/79379.

Burdett, Lois. "Hamlet for Kids (Shakespeare Can Be Fun!).” Accessed September 2, 2019. https://www.ama zon.com/Hamlet-Kids-Shakespeare-Can-Fun/dp/155 2095304.

Chambers, David, Ed. "Patrons and artists in the Italian Renaissance.” Accessed September 2, 2019. https:// www.palgrave.com/gp/book/9781349006236.

Dali, Salvador. Self Portrait Mona Lisa [photomontage]. https://www.dalipaintings.com/self-portrait-monalisa.jsp. Accessed September 2, 2019.

"Don Quijote de La Mancha" [novel]. Accessed June 4, 2015. https://es.wikipedia.org/wiki/Don_Quijote_de _la_Mancha.

“Don Quixote and Sancho Panza.” Accessed March 15, 2019. https://www.moma.org/collection/works/ 68157.
41 “Darwin's Beagle field notebooks (1831-1836)." Accessed

42 September 2, 2019. http://darwin-online.org.uk/Edi43 torialIntroductions/Chancellor_fieldNotebooks.html.

44 "Iracema" [painting]. Accessed June 3, 2016. https://pt. wikipedia.org/wiki/Ficheiro:Iracema_hi.jpg.

The Magna Carta. https://en.wikipedia.org/wiki/Magna _Carta. Accessed September 2, 2019.

Matisse's Rare 1935 Etchings for James Joyce’s Ulysses. https://www.brainpickings.org/2012/06/19/matisseulysses-1935/. Accessed 20 August 2019.

"Mona Lisa" [painting]. Accessed May 4, 2019. https:// en.wikipedia.org/wiki/Mona_Lisa.

Roberts, Andrew. "Napoleon: A Life." Accessed September 2, 2019. https://www.amazon.com/NapoleonLife-Andrew-Roberts/dp/0143127853.

Van Eyck, Jan. "The Ghent Altarpiece" Accessed June 3, 2018. https://www.khanacademy.org/humanities/renais sance-reformation/northern-renaissance1/burgundy-ne therlands/a/vaneyck-ghentaltar.

Van Gogh, Vincent. 1988. "To Theo van Gogh" [letter]. Accessed September 2, 2019.http://www.vangoghlet ters.org/vg/letters/let602/letter.html.

"Vermeer and the Masters of Genre Painting." [exhibition]. Accessed September 6, 2019.

https://www.nga.gov/exhibitions/2017/vermeer-and-the -masters-of-genre-painting.html.

Warhol, Andy. "Colored Mona Lisa" [silk screen]. Accessed September 26, 2018.

https://www.christies.com/lotfinder/Lot/andy-warhol1928-1987-colored-mona-lisa-5896014-details.aspx. 
C. H. Marcondes. Towards a Vocabulary to ImplementCulturally Relevant Relationships ...

Wilton, A. Painting and poetry: Turner's verse book and his work of 1804-1812. https://www.amazon.com/ Painting-Poetry-Turners-Verse-1804-

1812/dp/0295970936. Accessed September 7, 2018.

“Rembrandt catalog raisonné." 1986. Tümpel, Christian, Tümpel, Astrid, eds. H.J.W. Becht, Amsterdam. ISBN
9781904950929. Accessed May 5, 2019. https://en. wikipedia.org/wiki/Rembrandt_catalog_raisonn $\% \mathrm{C} 3$ \%A9,_1986.

"Rouen Cathedral (Monet series)." Accessed June 16, 2019. https://en.wikipedia.org/wiki/Rouen_Cathedral _(Monet_series). 